\title{
Biosecurity Adoption on Cattle Farms in Indonesia
}

\author{
V.S.Lestari ${ }^{1}$; S.N. Sirajuddin ${ }^{1}$ and A. Asnawi ${ }^{1}$
}

\begin{abstract}
The aim of this study was to know biosecurity adoption on beef cattle farms. This research was conducted for a month at Barru regency, South Sulawesi province, which famous as one of beef cattle breeding villages in Indonesia. Sample was choosed through random sampling. Total sampel was 30 beef cattle farmers. Data were collected through observation and interview. Biosecurity measures consisted of 35 indicators which was grouped into 4 namely: management practice, sanitation, disease and disease prevention, and calf management. Each indicator was devided into two groups: adopt and not adopt. Data were analysed descriptively. The results revealed that $47.4 \%$ of beef cattle farmers have adopted biosecurity on their farms and was catagorized as a "partial adopter". This percentage should be increased in order to increase meat production and food safety.
\end{abstract}

Keywords: adoption, biosecurity, beef cattle, farmers

\section{Introduction}

Biosecurity is defined as security from transmission of infectious diseases, parasites and pests. Biosecurity has focus on maintaining or improving the health status of animal and preventing the introduction of new disease pathogens by assessing all possible risks to animal health (Satyanarayana et al., 2008; Zavala, 2011; Muller et al., 2007; Fraser et al., 2010; Iqbal, 2009; Dorea et al., 2010; Julien and Thomson, 2011; Fasina et al., 2011). The aim of implementing biosecurity measures on cattle farms is: a) to preserve a high health status of animals by protecting them from new and existing pathogens and b) to ensure the production of safe food. General biosecurity measures should be implemented in any farm regardless of any specific problem (Valergakis et al., 2008).

Biosecurity has three major components: segregation, cleaning and disinfection (FAO, 2008). Biosecurity will not only maintain the good environment but also minimize infectious and zoonotic diseases and subsequently increase public health (Sharma, 2010). According to Brenan and Christley (2012), biosecurity measures on cattle farms consisted of animal movement, equipment sharing and companies and contraction visiting the farms. Valergakis et al. (2008) argued that the lack of professional attitude by farmers, the defective design and development, as well as the inadequate organization of Greek cattle farms, are the main obstacles in implementing biosecurity measures. But, part of the responsibility lies on the veterinary profession as well; lack of training and motivation is the most probable explanation. 
Adoption is a process of receiving an innovation, hopefully there is a change in cognitive, affective, and psychomotoric to any body who get innovation from extension worker (Ban and Hawkins, 1999). Using adoption index, biosecurity adoption of layer smallholders in South Sulawesi was classified into a "partial adopter". The low level of biosecurity at farm gate and traffic onto the shed can be enhanced by layer smallholders through voluntary adoption (Lestari et al., 2011). The adoption of biosecurity were associated with gender, age, education, farming experience, farm-income, family size and social capital. These variables contributed $20.00 \%$ variation on biosecurity adoption of laying hen farms. However, only farm income, family size and social capital were the major factors influencing to the adoption of biosecurity $(\mathrm{P}<0.05)$ (Lestari et al., 2012).

Barru regency was famous as a beef cattle breeding village in South Sulawesi province. The development of cattle farming were slowly. It is caused by several factors, such as farmers knowledge about cattle management practice is still low, farmers have cattle as saving, and they sell cattle when ever they need money. They used traditional (extensive) method, some of farmers don't provide housing for their cattle, some of farmers keep their cattle under their house. Beef cattle farmers usually gave low quality of grass especially in dry season. They still lack of technology such as urea molases block and artificial insemination. Ella (2002) stated that a). the low of cattle productivity both in quality and quantity was caused by in-breeding for a long time; b). decreasing productivity caused decreasing carcass weight and c). the limited of quantity and quality of feed.

Suriani (2009) said that in 2006 in Gowa regency as one of regencies in South Sulawesi provinces, 50 people were infected by anthrax. In 2009, 12 head of horses, 5 head of beef cattle and 2 head of buffaloes dead because of anthrax. Anonymous (2009) added that in 2008, 3 head of beef cattles dead in Gowa regency. In addition, 11 people were infected, so isolation and vaccination were done by Animal Husbandry Service. According to Suriani (2011), 30 cows died suddenly at the same place. Therefore, vaccination, blood and serum sampling were conducted.

Demand for meat increased according to population, and community welfare. To fulfill demand for meat in Indonesia, Indonesia imported $40 \%$ of total meat demand from Australia, New Zealand and the United States. According to Jefriando (2014), imported meat increased more than twice: from $6,193,000$ ton (US\$ 24,801 million) to $13,525,000$ ton (US\$ 58,633 million) in January 2014 and March 2014 respectively. Indonesian government made many regulation to the development of beef cattle production. One of them is biosecurity. Biosecurity is important to be implemented on beef cattle farms in order to increase meat production and food safety.

The study was undertaken with the following objective to determine the level of biosecurity adoption on beef cattle farms in Barru regency, South Sulawesi province, Indonesia.

\section{Research Method}

This research was conducted in Barru regency for a month. Sample was choosed through random sampling. Total sample was 30. Data were collected through observation and interview. Biosecurity measures were devided into 4 steps adopted from 
Buhman et al. (2007) namely good management practice, sanitation, disease and disease prevention, and calf management. Biosecurity measures consisted of 35 questions. Biosecurity adoption on beef cattle farms were categorized into two groups: adopt (score 1) and not adopt (score 0). Data were tabulated using frequency distribution and were analysed descriptively.

The adoption level of the respondents was measured by making use of adoption index (Karthikeyan, 1994 in Rahman, 2007).

Adoption index $=\frac{\text { Respondent total score }}{\text { Total possible score }} \times 100$

Depending upon the extent of adoption of biosecurity measures, the respondents were categorized as follows: (1) Low adopters (up to 33\%); (2) Partial adopters (34-66\%) and (3) High adopters (67-100\%).

\section{Results and Discussion}

\section{a.The characterisctics of respondents}

Characteristics of respondents can be seen in Table 1.

Table 1. Characteristics of Respondents

\begin{tabular}{lllll}
\hline Item & Mean & Sd & Minimum & Maximum \\
\hline Age (year) & 42.1 & 10.5 & 25.0 & 61.0 \\
Education (year) & 12.9 & 5.05 & 6.0 & 19.0 \\
Farm experience (year) & 16.7 & 1.7 & 1.0 & 40.0 \\
Number of family (person) & 4.0 & 2.0 & 1.0 & 11.0 \\
Number of beef cattle (head) & 8.0 & 6.0 & 2.0 & 30.0 \\
\hline
\end{tabular}

Table 1 showed that the average of age respondents was 42.1 years. This mean respondents were in a productive age. To look after cattle, manpower was needed. The average length of their education was 12.9 years. This mean that respondents were well educated because they finished their formal study at senior high school. They can make a good decision. The average of respondents farm experience was 16.7 years. This mean that respondents have long experience to handle of their beef cattle. Number of family of respondents was 4.0 person. Family can help look after their cattle. The average number of beef cattle was 8 heads.

\section{Biosecurity Adoption}

Biosecurity adoption on beef cattle farms can be seen in Table 2 .

Table 2. Biosecurity Adoption on Beef Cattle Farms

\begin{tabular}{llll}
\hline No & Biosecurity measures & Adopt (\%) & Not Adopt (\%) \\
\hline 1 & Management practice & 46.70 & 53.30 \\
2 & Sanitation & 55.70 & 44.30 \\
3 & Disease and disease prevention & 42.11 & 57.89 \\
4 & Calf management & 48.33 & 51.67 \\
\hline & Total & & 57.40 \\
\end{tabular}


As can be seen in Table 2., the highest level of biosecurity measures was sanitation $55.7 \%$. This included sanitation on feedstuff, tools and equipments. While the lowest biosecurity adoption was disease and disease prevention (42.11\%). Therefore, veterinarian or extention staff should more intensive in giving information about diseases prevention. Total biosecurity adoption level was $47.40 \%$. Respondents can be categorized as partial adopters, because the percentage was between 34-66\% (Karthikeyan, 1994 in Rahman, 2007). This research agree with that of Lestari et al. (2011).

\section{Conclusion}

Based on the results, it can be concluded that the level of biosecurity adoption on beef cattle farms in Barru regency, South Sulawesi province, Indonesia was categorized as "low adopter". Veterinarian or extention staff should more intensive in giving information about good management practices.

\section{References}

Anonim. (2009). Sulawesi Selatan Waspadai Ancaman Antrax. Retrieved from www.antaraSulawesiSelatan.com/berita/10138/sulsel-waspadai-ancaman-antrax.

Anonim. (2013). Swasembada Daging Sapi 2014. Retrieved from Indonesiancompanynew.wordpress.com.

Brenan, M.L. \& Christley, R.M., (2012). Biosecurity on cattle farms: A study in North-West England. PloS One, 7 (1), e28139.

Dorea, F.C., Berghaus. R., Hofacre.C, \& Cole. D.J., (2010). Survey of biosecurity protocols and practices adopted by growers on commercial poultry farms in Georgia, U.S.A. Avian Diseases, 54 (3), 1071015.

Ella A., (2002). Crop livestock system di Sulawesi Selatan : suatu tinjauan pelaksanaan kegiatan. Wartazoa, 12 (1), 18-23.

FAO. (2008). Biosecurity for highly pathogenic Avian influenza. Animal Production Health Paper. Rome. Italy.

Fasina, F.O., Ali. A.M., Yilma. J.M., Thieme. O., \& Ankers. P. (2011). The cost-benefit of biosecurity measures on infectious diseases in the Egyptian household poultry. Preventive Vet. Med, 103 (2-3), 178-191.

Fraser, R.W., William, N.T. Powel, L.F., \& Cook, A.J.C. (2010). Reducing Campylobacter and Salmonella infection: two studies of the economic cost and attitude to adoption of on-farm biosecurity measures. Zoonoses and Public Health, 57 ( 7/8), e109-e115.

Iqbal, M., (2009). Controlling avian influenza infections: the challenge of the backyard poultry. Journal Mol. Genet. Med, 3 (1), 119-120.

Jefriando, M. (2014). Tiap bulan naik, RI impor daging dan sapi hidup Rp 2,7 triliun di kuartal I-2014. Retrieved from: finance.detik.com/read/2014/05/05/152437/2573524/tiap-bulan-naik-ri-impor-dagingdan-sapi-hidup-rp-27.

Julien, D \& Thomson. S., (2011). Interactive methods to educate and engage poultry producers on the importance of practicing on-farm biosecurity. Journal of Agric. Ext.and Rur. Dev. 3 (8): 137-140.

Lestari, V.S., S.N. Sirajuddin, \& K. Kasim., (2011). Adoption of biosecurity measures by layer smallholders. J. Inter.Trop.Agric. 36 (4): 297-302.

Lestari, V.S., Natsir.A., Sirajuddin, S.N., Kasim. K., Ali. H.M., Saadah, \& Mawardi. (2012). Factors affecting to biosecurity adoption on laying hen farmers. J. Inter.Trop.Agric. 37 (4), 302-307.

Muller, C., Kancans, R., \& Carr. A., (2007). Biosecurity and Small Landholders in Peri-Urban Australia. Australian Government. Bureau of Rural Sciences. Canberra ACT.

Rahman, S. (2007). Adoption of improved technologies by the pig farmers of Aizawi district of Mizoram, India. Livestock Research for Rural Development,19, Article \#5. Retrieved from bttp:// wmw.Irrd.org/Irrd19/1/ rahm19005.btm. 
Satyanaraya, S.K.V.IAS., Reddy. M.N., Balasubramani.N, Chandrashekara.P, Rao. K.H., \& Santakki. B.S., (2008). Sustainable Livestock. Development. National Institute of Agricultural Extension Management (MANAGE). Andhira Pradesh, India.

Sharma, B. (2010). Poultry production, management and bio - security measures. J. Agric. and Env. Review Paper, 11: 120 - 124.

Suriani. (2009). Virus Antrax Menyerang Makassar. Retrieved from metropolitan.inilahcom/ read/detail/114317/virus-antrax-menyerang-Makassar \#U3SHOXZm=I.

Suriani. (2011). Ratusan Sapi di Gowa Divaksin Antrax. Retrieved from Nasional.inilabcom/read/detail/1776556/ratusan-sapi-di-gowa-divaksin-Antrax\#.U3SiuHZm=I.

Zavala. (2011). Viral Respiratory Disease of Poultry: A continuous challenge. Poultry Disease. This paper was presented at the XVII World Veterinary Poultry Association Congress in Cancun, Mexico, August 14-18, 2011.

Valergakis, G.E.; Arsenos, G.; Oikonomou, G. (2008). Biosecurity measures on cattle farms (In Greek). Journal of the Hellenic Veterinary Medical Society, 59 (1), 9-22(14).

Van den Ban, A.W. and Hawkins. H.S. (1999). Penyuluhan Pertanian. Yogyakarta, Penerbit Kanisius. 
